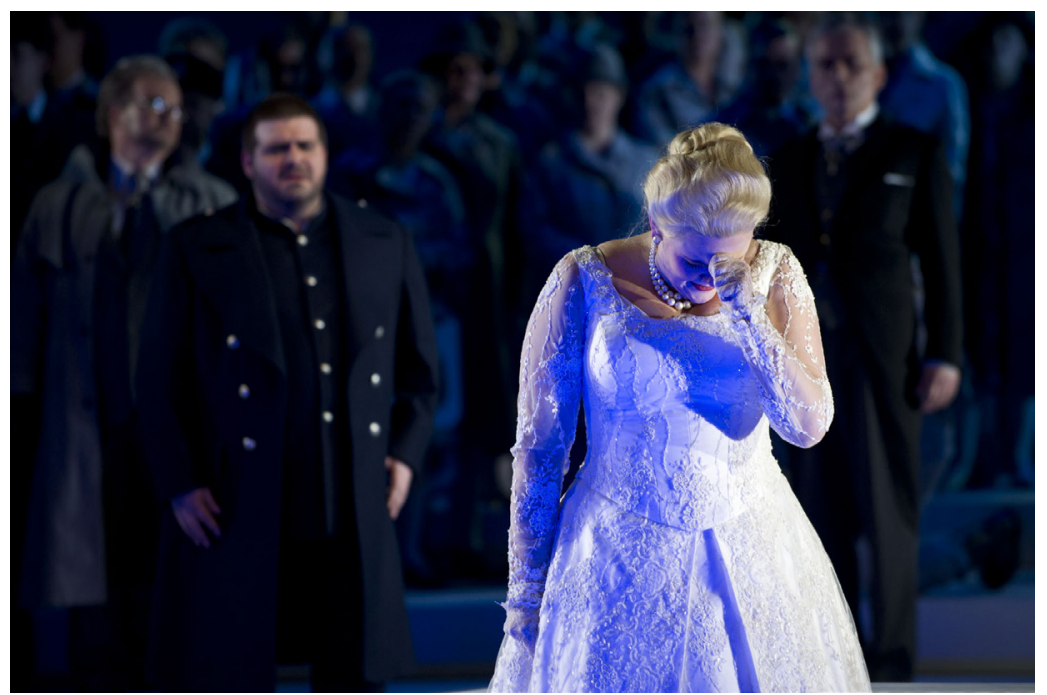

Lohengrin (Richard Wagner). Emma Vetter (Elsa) and Michael Weinius (Lohengrin), Royal Opera, Stockholm, 20I 2. Photographer: Alexander Kenney. Copyright CC-BY-NC-ND, Royal Opera, Stockholm. 


\section{No Questions Asked: Wagnerian Love Ban in Lohengrin}

The fascination of operatic art resides in its abundance. Liberated from the constraints of realism and probability, the spectator can surrender to it or to turn away entirely, and enjoy it like an oyster: either swallowed whole or not at all. ${ }^{\mathrm{I}}$ The critical operagoer, particularly a feminist one, has many challenging positions to negotiate. Will the confrontation lead to a rejection of the entire genre?

Susan McClary observes that the aspect of music that is most difficult to account for is its almost frightening ability to make our entire body respond to its rhythms. ${ }^{2}$ What, then, would opera be without music? What would remain if the music were stripped away and all that were left was the libretto? Could it stand on its own? The text of an opera or musical drama represents a unique genre. Unlike other dramatic texts, an opera's libretto is made whole only by the musical accompaniment and the events that accompany it on stage. A libretto is generally shorter and more fragmentary than any other type of dramatic text because it takes at least three times longer to sing a piece than to recite it. One needs to leave room for the music: the form demands it. ${ }^{3}$

Nevertheless, it should be possible to carry out a dispassionate reading of a libretto, as we shall here attempt with Richard Wagner's Lohengrin (I848). It seems impossible to consider Lohengrin without its music; however, the reverse is also true. Wagner wished to unite the verbal with the musical in order to create a Ton-Wort-Drama. Combined with the score and the spectacle that unfolds on stage, this new form of drama was supposed to be a Gesamtkunstwerk (unified work of art) that Wagner hoped would establish stagecraft as a hyper-art.

How to cite this book chapter:

Rosenberg, Tiina 20I6. No Questions Asked: Wagnerian Love Ban in Lohengrin. In: Rosenberg, Tiina Don't Be Quiet, Start a Riot! Essays on Feminism and Performance. Pp. 22-50. Stockholm: Stockholm University Press. DOI: http://dx.doi.org/Io.I6993/baf.b. License: CC-BY 4.0 
In order to examine the fate of Lohengrin's female lead Elsa from a feminist perspective we first should consider what that perspective means. Gayle Austin defines it as follows:

A feminist approach to anything means paying attention to women. It means paying attention when women appear as characters and noticing when they do not. It means making some 'invisible' mechanisms visible and pointing out, when necessary, that while the emperor has no clothes, the empress has no body. It means paying attention to women as writers and as readers or audience members. It means taking nothing for granted because the things we take for granted are usually those that were constructed from the most powerful point of view in the culture, and that is not the point of view of women. ${ }^{4}$

One of the basic principles that feminist theory shares with other theories of cultural criticism is that seeing/reading/listening can never be neutral. It is always bound up with a specific historical context and is expressed from a particular cultural perspective. A woman has a dual focus (what has been called a sidelong glance), looking simultaneously in two directions. ${ }^{5}$ Thus, feminist aesthetic analysis must begin with the fact that a woman is defined - to use Simone de Beauvoir's terminology - as "the other" and is taught to regard herself as such. However, "other" here must not be confused with otherness, which is a potentially positive marker of gender difference denoting the ordinal position of being second, that is, coming after the first, masculine gender.

The basic rule for a feminist reading of dramatic texts is that the reader must resist the canonized masterpieces of dramatic literature. ${ }^{6}$ The same principle may be applied to their traditional interpretations. A feminist reading is here combined with an empathetic approach, assuming that the assessment of any work must be contextual. The feminist viewpoint clashes undeniably with Wagner's notion of women, whereas a patient, less single-minded reading may help us understand and enjoy Lohengrin more fully.

\section{Woman as outsider}

A patriarchally constructed and managed theatrical institution assigns women a special position. The long tradition of women appearing on stage has them dancing, singing, undressing, and 
dressing in front of the relentless, often admiring gaze of the audience. As Ann Kaplan writes, "Men do not simply look; their gaze carries with it the power of action and of possession that is lacking in the female gaze. Women receive and return a gaze, but cannot act on it." 7 Not being in possession of a subject position and gaze is concomitant with the more general exclusion of women from the sphere of the arts.

Mimesis, as defined by Aristotle, characterizes not only poetry, but encompasses theatre as well. In the fourth chapter of his Poetics, he identifies mimesis as an aspect of human nature, and uses the concept to express the step from the social world into the realm of poetry. ${ }^{8}$ According to Aristotle, imitation is a fundamental human need. Although he was probably referring to both women and men, mimesis in ancient Greek theatre excludes women. The concept is a masculine one, defined by and for men. In Feminism and Theatre, Sue-Ellen Case points out that mimesis also bars women from the sphere of aesthetic experience in general. She finds the definitions in the Poetics based on a combination of social reality and aesthetic rules that render women outsiders in both areas. ${ }^{9}$

Not only are women excluded from the aesthetic system in general; according to Case their function in drama is to set boundaries for the masculine subject in order to facilitate the plastic definition of his outline, or, alternatively, illustrate ways in which women differ from men. Such a gender difference is expressed by clarifying male characteristics at the expense of women's. Case concludes that the woman is made invisible, and this invisibility creates an empty space that turns our attention to the masculine subject. The effect is that women are shown as subjects only insofar as they contribute to the definition of the male character. ${ }^{10}$

In her I 978 feminist theatre manifesto “Aller à la mer," Hélène Cixous proclaims that going to the theatre for a woman is like going to her own funeral. The key issue for Cixous is how women can attend the theatre without being complicit in the institutional sadism directed against them. The female spectator occupies the victim's position within the patriarchal family structure that is repeated ad nauseum in the theatre. Who is this female victim? As examples of women victimized in drama Cixous lists Electra, Antigone, Ophelia, and Cordelia. "In every man," Cixous writes, 
"there is a dethroned King Lear who requires his daughter to idealize him: 'Tell me that I am the greatest, the me-est, the most like a king, or I'll kill you!'” ${ }_{I I}$

\section{Women and opera}

As stated in Chapter I, the discourse on women and opera is dominated by two approaches. The first sees women as victims of operatic art - victims who have no voice and no subject position. Catherine Clément analyzes opera as a sacrificial rite in which the entire operation is in the hands of men. Women, however independent or active they may appear, are sacrificed, particularly if they are rebellious women. According to Clément, what is relevant is not that women in operas die (men die, too), but how they die. And there are so many ways to die. Carmen, Gilda, Butterfly, and a number of others die from a stab wound, some by their own hand. Violetta and Mimi die of tuberculosis. Norma, Brünnhilde, and Jeanne d'Arc are burned at the stake. Senta and Tosca leap to their deaths. Some drown or are poisoned, others die of a variety of causes, like Antonia, Isolde, and Mélisande. ${ }^{12}$

Carolyn Abbate offers another perspective on women in opera. In contrast to Clément she claims that opera actually gives voice to women. While librettists provide relatively little character leeway for women, vocally the opera offers them much greater latitude than the classical theatre. ${ }^{\mathrm{I}}$ It is not the score, but the experience of a voice that has the capacity to overcome the "masculinity" of a piece of music. The voice is able to vibrate and convey new and unexpected meanings.

Wagner's intense female voices represent a turning point in the history of the theatre. In contrast to the young dramatic spinto sopranos in bel canto, Wagner's women generate a larger volume of sound than any female operatic heroines had done before. The unusually deep orchestra pit in Wagner's Festspielhaus in Bayreuth also has the effect of amplifying the singers' voices, carrying them over and above the sounds of the orchestra. This serves Wagner's aim of creating a vocal style in which music and language merge, so that the declamation of the dramatic text is enunciated clearly.

Abbate's idea of opera as an opportunity to give voice to women is based on the musicological texts of Roland Barthes in 
which he discusses what he calls, le grain de la voix, the grain of the voice. ${ }^{\mathrm{I}}$ Barthes conceives of the voice as a new kind of author, singing inside every text. Music and voice both take something that is linguistically unarticulated and raise until it becomes a new entity. That articulation resounds in the listener, who is charmed by it. Voice is that elusive element in which body and language meet without merging completely.

In the musical fusion of the abstract and the concrete/corporeal we can glimpse Barthes's dream of an art form that lacks any system of signifier/signified. ${ }^{15}$ Questioning the hierarchical and gendered subject-object positions of traditional aesthetics is one way to search for alternative modes of understanding. Barthes, who seldom uses the terms of gender theory in his arguments, ascribes to the voice the power of femininity. According to him, the "grain" of the voice is the materiality of the body speaking in its mother tongue. Setting the voice in opposition to the masculine logos is a common device in French psychoanalytic and feminist theory, which often emphasizes the prelinguistic stage as one of femininity and maternity.

Set against this background, Barthes's arguments can be seen as approaching the Western cliché of the "femininity" of music. In fact, Wagner, in an essay entitled "Oper und Drama," writes that music is a woman. ${ }^{16}$ Voice is a singular phenomenon, a noncategory. In its vibration it goes beyond the classical linguistic signifier and becomes a throbbing that rises from the depths of the human body. The singer's voice conjures up another realm, a realm of meaning beyond language. Enraptured listening is a path that takes us to this space; but in addition to direct experience, it requires of us knowledge of aesthetic structures that are both gendered and hierarchical.

\section{Women in Wagner's oeuvre}

Wagner's writings, his operas in particular, demonstrate a considerable interest in women and femininity. The notion of women that appears in his texts is essentialist: men are active, woman are passive. A woman not only receives a man's sperm and bears his children, but her soul and will are completely dependent on him. A woman loves because she must, Wagner declares in an essay on "Oper und Drama." ${ }^{17}$ Without love, a woman is nothing. 
Impossible and irreconcilable love is a recurring Wagnerian theme. Nearly all the women in his operas take great risks in trying to integrate their loves and their lives; it belongs to their utopian potential. That is why a woman's fall is so profound and her tragedy so great. A good woman is a loving woman, and most heroines in Wagner's operas are good according to his standards of loving and suffering. The only evil woman in Wagner's operas is Ortrud, Elsa's rival in Lohengrin. She represents a demonic woman who only has her own interests at heart and does not shrink from political power.

Wagner's female roles can be divided among the following types, some of which overlap:

I. The innocent victim: Ada (Die Feen), Senta (Der fliegende Holländer), Elisabeth (Tannhäuser), Elsa (Lohengrin), Brünnhilde (Der Ring des Nibelungen), Isolde (Tristan und Isolde)

2. The self-sacrificing, loving woman: Senta (Der fliegende Holländer), Elisabeth (Tannhäuser)

3. The mistress: Venusberg women (Tannhäuser), Sieglinde and Gutrune (Der Ring des Nibelungen), Isolde (Tristan und Isolde), Eva (Die Meistersinger von Nürnberg)

4. The wife: Mariana (Liebesverbot), Ortrud (Lohengrin), Fricka (Der Ring des Nibelungen), the noblewomen of the chorus (Tannhäuser)

5. The evil, power-thirsty woman: Ortrud (Lohengrin)

6. The seductress who longs to be saved: Kundry (Parsifal)

7. The witch: Dilnovaz (Die Feen)

8. The sister: Lora (Die Feen), Isabella (Liebesverbot), Irene (Rienzi)

9. The loyal maidservant: Drolla (Die Feen), Dorella (Liebesverbot), Brangäne (Tristan und Isolde)

ıо. A woman dressed as a boy (Wagner's trouser roles): Adriano (Rienzi), a messenger of peace (Rienzi), four nobles and a young shepherd (Tannhäuser), and an esquire (Parsifal)

I I. Mythological characters:

a) Goddesses: Venus (Tannhäuser), Erda, Fricka, Freia (Der Ring des Nibelungen) 
b) Demigoddesses: Brünnhilde, the Norns, Rhine maidens, other Valkyries

c) Fairies (Ada, Zemira, Farzana) and other embodiments of nature, such as birds in the forest and flower maidens $^{18}$

Wagner almost invariably introduces love on the operatic stage through female characters. In Der fliegende Holländer, he describes Senta as "the woman of the future." 19 She sacrifices herself out of love to save a man. Here Wagner follows the motif of "redemption through the woman," of which Gretchen is the paradigm in the first part of Goethe's Faust. However, the endless sacrifices and love projects of Wagner's women are doomed to fail when they come up against men's actions and power. The same conflict between love and reality is found throughout Wagner's operas, including Lohengrin.

\section{Lohengrin: Synopsis}

Lohengrin is an opera in three acts that stylistically lies somewhere between a romantic opera and Wagner's later conception of a music drama. It is based on the medieval legend of a mysterious knight who arrives in a swan-drawn carriage to rescue a woman in distress. Overcoming the enemy, he takes her as his wife, but forbids her ever to ask him his name or origin. When she eventually does, he leaves her, never to return. The first German language version of the Lohengrin legend is Parzival, written around I 2 Io by Wolfram von Eschenbach, from which the characters in Wagner's opera are taken.

In Act I of Lohengrin, King Heinrich of Germany (bass) arrives in the rich Duchy of Brabant to levy a tax. He notes that disputes have arisen in the town since the death of the late Duke. The Duke's successor, Friedrich von Telramund (baritone), instead of giving the king an explanation, accuses Elsa von Brabant (soprano) of causing the disappearance of her younger brother, Gottfried (mute role). Telramund, in addition to being Elsa's and Gottfried's godfather, is also Elsa's rejected suitor. When the accusation is compounded by the possibility of fratricide, King Heinrich sees no alternative but to refer the matter to God's judgment. When no one appears to defend Elsa, she desperately prays that God may 
send her a champion in the person of a knight she saw in a dream. Miraculously, that knight (tenor) does appear, borne by a swan. He is ready to do combat for Elsa, but he requires of her that she never ask him his origin or name. Elsa gives her word. The knight confesses his love for her and she has no hesitation in agreeing to be his wife. The unknown knight then defeats Telramund in combat, but spares his life.

Telramund's wife, Ortrud (soprano/mezzo-soprano), is an ambitious woman and in Act II she works her manipulations on Telramund and Elsa. In Act III Elsa poses the forbidden question to her husband by asking him his name. Furious, he accuses her of betraying his trust. Now the knight must disclose his identity. He reveals that he is Lohengrin, the son of Parsifal, known to all from the story of the Holy Grail. After this announcement he must return to the Grail. Grieving, he bids farewell to the forlorn Elsa, leaving her his sword, a silver horn, and the ring of the Grail. Ortrud is overjoyed and convinced that she has now gained ascendancy in Brabant. At that moment Elsa's brother, Gottfried, reappears and is proclaimed the new ruler by Lohengrin.

The story of Lobengrin is a mixture of classical tragedy, Christian mythology, and nineteenth century melodrama. Following the latter's conventions, the characters represent polar opposites, such as good and evil or sin and innocence. Antagonists (Ortrud/Telramund) and protagonists (Elsa/Lohengrin) comprise the fundamental dramatic types. The drama begins with a moral conflict, the key theme of which involves sexual identity - particularly female virtue and purity. The virtuous woman suffers more deeply and sings with greater poignancy than all the rest.

\section{Overture}

The external story in Lohengrin is about combat and other characteristically masculine conflicts, whereas the internal story is about the unhappy love between Elsa, an earthly woman, and Lohengrin, a divine hero. The dramatic precision and consistency of the internal action rests on several elements: the prelude, Elsa's dream, the injunction against questioning, and its violation, and the climactic story of the Holy Grail in Act III. 
The music in Lohengrin inhabits several worlds: the sphere of military conflict, Lohengrin's quest for the Grail, and, by contrast, the pagan world of black magic represented by Ortrud and Telramund. For the most part, Wagner keeps these worlds apart until the encounter between Elsa and Lohengrin. The pair's solemnity is the mood that pervades the opera. ${ }^{20}$

In an article on Lohengrin, Helga-Maria Palm finds the opera emotionally barren, since feelings are not openly expressed. ${ }^{2 I}$ However, even if they cannot be seen, the emotions can be heard: the opera is permeated with longing and renunciation. The love of the Grail knight for the virgin Elsa remains unrequited. Pure love does exist between them, but a bodily union never takes place. The earthly and the heavenly cannot become one.

The internal action finds its finest expression in the prelude, built around the Grail theme as a symbol of sublime good. This symphonic poem establishes the emotional climate for the opera. It opens with a long crescendo played by the strings that seem to be holding their breath, accompanied by a few woodwinds alternating with the whispered pianissimo notes of a solo violin. The Grail theme is stated by the woodwinds together with the strings in a lower register, then by an English horn; and the climax is supported by trombones, trumpets, and a tuba.

The dramaturgy of the prelude tells the story of how the miraculous Grail was sent down to the earth, revealed to the people, and then taken up into the heavens again. As the goblet used in the Last Supper, the Grail is possessed of miraculous powers. According to legend, Joseph of Arimathea collected the blood of the Christ in it. Somehow the Grail has come into the possession of knights in distant Montsalvat in the Pyrenees. The sombre mood of the prelude suffuses the music of the internal action of the opera, the love between Elsa and Lohengrin. The Grail leitmotif, used sparingly in Act I, is heard in its entirety in the retelling of the story of the Grail that concludes the opera.

\section{Elsa's dream (Act I, Scene 2)}

Following the stately prelude, we are cast into the abrasive, masculine world of political conflict and warfare. A fanfare announces 
the royal presence, and a large male chorus backs the heavy voices of the two rulers, King Heinrich and Duke Telramund. When Elsa is called into the King's presence to defend herself from the accusations against her, the music shifts to the pale tones of the woodwinds. For Wagner, the oboe represents ingenuousness, innocence, and chastity, but he also associates it with lament, yearning, and pain. ${ }^{22}$ Wagner increased the number of flutes, oboes, and bassoons in Lohengrin. The oboe is also used in conjunction with Elsa's counterparts, Senta in Der fliegende Holländer, and Elisabeth in Tannhäuser.

Elsa's dream state is signaled by a melody in the oboe that evokes her inner world. At her first appearance she approaches men timidly, but without fear. Charges are hurled at her, yet she remains abstracted and introspective. She stands alone, supported only by the female chorus that raises its voices when no one else is willing to defend her.

Elsa's dream is in three parts. The first, Einsam in trüben Tagen (Lonely, in troubled days) relates the hopelessness of her predicament. She then describes the knight who appears to her in her dream, In lichter Waffen Scheine (In splendid, shining armour), confident that he will come to her rescue. In the third part, she repeats the lines des Ritters will ich wabren, er soll mein Streiter sein (I will wait for the knight; he shall be my champion) as the time frame shifts to the future.

\begin{tabular}{|l|l|}
\hline Elsa: & Elsa: \\
Einsam in trüben Tagen & Lonely, in troubled days \\
hab' ich zu Gott gefleht, & I prayed to the Lord, \\
des Herzens tiefstes Klagen & my most heartfelt grief \\
ergoss ich im Gebet. & I poured out in prayer. \\
Da drang aus meinem Stöhnen & And from my groans \\
ein Laut so klagevoll, & there issued a plaintive sound \\
der zu gewalt'gem Tönen & that grew into a mighteous roar \\
weit in die Lüfte schwoll: & as it echoed through the skies: \\
Ich hört' ihn fernhin hallen, & I listened as it receded into the \\
distance
\end{tabular}




\begin{tabular}{|l|l|}
\hline Elsa: & Elsa: \\
In lichter Waffen Scheine & In splendid, shining armour \\
ein Ritter nahte da, & a knight approached, \\
so tugendlicher Reine & a man of such pure virtue \\
ich keinen noch ersah: & as I had never seen before: \\
ein golden Horn zur Hüften, & a golden horn at his side, \\
gelehnet auf sein Schwert, & leaning on his sword - \\
so trat er aus den Lüften & thus he appeared to me \\
zu mir, der Recke wert; & from nowhere, this warrior true; \\
mit züchtigem Gebaren & with kindly gestures \\
gab Tröstung er mir ein; & he gave me comfort; \\
(mit erhobener Stimme) & (in a louder voice) \\
des Ritters will ich wahren, & I will wait for the knight, \\
(schwärmerisch) & (dreamily) \\
er soll mein Streiter sein! & he shall be my champion! \\
\hline
\end{tabular}

Elsa:

(hat Stellung und schwärmerische Miene nicht verlassen, alles blickt mit Gespanntheit auf sie; fest)

Des Ritters will ich wahren, er soll mein Streiter sein! (ohne sich umzublicken) Hört, was dem Gottgesandten ich biete für Gewähr: In meines Vaters Landen die Krone trage er; mich glücklich soll ich preisen, nimmt er mein Gut dahin will er Gemahl mich heissen, geb' ich ihm, was ich bin! ${ }^{24}$
Elsa:

(She still looks enraptured; everyone watches her in expectation) I will wait for the knight, he shall be my champion! (without looking round) Hear what reward I offer the one sent by God: in my father's lands he shall wear the crown. I shall consider myself happy if he takes my possessions if he wishes to call me spouse, I shall give him all that I am!

In the dream story, the dramatic focus gradually moves away from Elsa's lamentation and increasingly onto the knight whom she is convinced will come to her aid. Elsa's situation is one of utter helplessness: no one is willing to fight for her. In the first part of the dream, this helplessness is expressed, but no male voices are heard. In the second and third parts, there are short interjections 
by King Heinrich and the male chorus, and the strings tacitly play the Grail leitmotif in anticipation of the knight's entrance.

Elsa is not the only character in Wagner to draw a man to her telepathically, as it were: in Der fliegende Holländer (Act II, Scene 3), Senta recounts a similar dream:

\begin{tabular}{|l|l|}
\hline Senta: & Senta: \\
Versank ich jetzt in wunderbares & Am I deep in a wonderful \\
Träumen, & dream? \\
was ich erblicke, ist es Wahn? & What I see, is it mere fancy? \\
Weilt' ich bisher in trügerischen & Have I been till now in some \\
Räumen, & false world, \\
brach des Erwachens Tag & is my day of awakening \\
heut an? & dawning? \\
Er steht vor mir mit leidenvollen & He stands before me, his face \\
Zügen, & lined with suffering, \\
es spricht sein unerhörter Gram & it reveals his terrible grief \\
zu mir. & to me: \\
Kann tiefen Mitleids Stimme & can deep pity's voice lie \\
mich belügen? & to me? \\
Wie ich ihn oft gesehn, so steht & As I have often seen him, here \\
er hier. & he stands. \\
Die Schmerzen, die in meinem & The pain that burns within \\
Busen brennen, & my breast, \\
ach! dies Verlangen, wie soll ich & ah, this longing, how shall I \\
es nennen? & name it? \\
Wonach mit Sehnsucht es dich & What you yearn for, \\
treibt - das Heil, & salvation, \\
würd' es, du Ärmster, dir durch & would it came true, poor man, \\
mich zuteil!25 & through me! \\
\hline
\end{tabular}

Dramatic Sprechgesang, a kind of German recitative, is a particular way of treating language and dialogue. Lohengrin has his own, distinctive vocal melody, which, Palm suggests, together with the instrumentation, are the most important dramatic means of expression in the opera. ${ }^{26}$ They both are used to advance the plot, whereas the purely orchestral passages only play a supportive and accompanying role. 
Elsa's dream exemplifies vocal melody. The dream story is a coherent, systematically constructed verbal composition in which the evocation of a mood of lamentation is underscored by the choice of lyrics and the use of vowels. The mournful sound is created with vowels, especially the open $A$ vowel:

da drang aus meinem Stöhnen / ein Laut so klagevoll, der zu gewalt'gem Tönen / weit in die Lüfte schwoll.

As Elsa falls asleep, Wagner brings the open $A$ sound together with an alliterative phrase based on the $S$ sound. The lament weakens and dissipates in sibilants: "Mein Aug' ist zugefallen, ich sank in süssen Schlaf." ${ }_{27}$

Then the miracle Elsa witnesses in the dream comes true, and a knight approaches in a boat drawn by a swan. Lohengrin's entrance is a choral epiphany in which the knight of the Holy Grail descends from the heavens to defend and save the innocent Elsa. In keeping with the structure of classical Aristotelian drama, many nineteenth-century operas and melodramas included a scene in which a revelation or an act of recognition gives a new, unexpected turn to events. Often the scene is built around the figure of a mysterious stranger. In Lohengrin this first takes place with the arrival of the knight, and it occurs once more in connection with the Grail story that brings the opera to a close. Lohengrin's magnificent entrance as the heavens part is a theatrical convention that satisfies the formulaic requirement of visual extravagance.

An important aspect of the emotional dramaturgy of the dream is that Elsa expects to receive not only help, but also gain a husband who will inherit her father's kingdom. In the libretto, her willing subjugation is explicit: geb' ich ihm alles, was ich bin (I shall give him all that I am). Elsa's submission is a token of her boundless gratitude for Lohengrin's heroic act and includes agreeing to his injunction against asking his name.

\section{The Forbidden Question (Frageverbot) (Act 1, Scene 3)}

The love that is kindled between Lohengrin and Elsa signifies the union of the heavenly and the earthly spheres, although it is conditional in Lohengrin's case: 


\begin{tabular}{|l|l|}
\hline Lohengrin: & Lohengrin: \\
Elsa, soll ich dein Gatte & Elsa, if I am to become your \\
heissen, & husband, \\
soll Land und Leut' ich & if I am to protect country and \\
schirmen dir, & people for you, \\
soll nichts mich wieder vor dir & if nothing is ever to take me \\
reissen, & from you, \\
musst eines du geloben mir: & then you must promise me one thing: \\
(sehr langsam) & (very slowly) \\
Nie sollst du mich befragen, & Never shall you ask me, \\
noch Wissens Sorge tragen, & nor trouble yourself to know, \\
woher ich kam der Fahrt, & whence I journeyed, \\
noch wie mein Nam' und Art! & what my name is, or what my origin! \\
Lohengrin: & Lohengrin: \\
(gesteigert, sehr ernst) & (with passion, very earnestly) \\
Elsa! Hast du mich wohl & Elsa! Do you understand what I \\
vernommen? & am saying? \\
(noch bestimmter) & (even more forcefully) \\
Nie sollst du mich befragen, & Never shall you ask me \\
noch Wissens Sorge tragen, & nor trouble yourself to know \\
woher ich kam der Fahrt, & whence I journeyed, \\
noch wie mein Nam' und Art!28 & what my name is, or what my origin! \\
\hline
\end{tabular}

This injunction, which also has a musical refrain related to Lohengrin's leitmotif, is the key to the fundamental conflict in Lohengrin. After it has been stated, the spectator watches the question begin to grow in Elsa's mind. It comes as a warning from somewhere between the world of the Grail and the realm of Ortrud's black magic, and acts to draw together and force apart. The divine cannot be joined with the human: to try is to commit an act of hubris that contains the seed of disaster. ${ }^{29}$

The attempts of heroines in Wagner's operas to create a space for love are defeated by the deeds and power of men. In Elsa's case, Telramund, the rejected suitor, conspires with Ortrud to raise a false accusation of fratricide. Although King Heinrich is a benign patriarch, he must judge the matter according to the prevailing norms. Elsa's unhappy fate is not due to the malicious scheming of 
Telramund and Ortrud, but to Lohengrin's severe demand. We know that as a knight of the Grail he must not disclose his true identity, but he can also not reveal to Elsa that, were she only to wait one year, he would be relieved of his obligations toward the Grail and would be able to remain with her forever.

From Elsa's perspective, her beloved's withholding knowledge of his identity is cruel. Since naming is knowledge, and knowledge is power, she is rendered powerless by being excluded from that knowledge. Lohengrin's primary responsibility had been to discharge his duties as knight, and only secondarily, if at all, to become involved with a woman. From a feminist perspective, the story may be turned inside out so that the fairness and justification of Elsa's question to Lohengrin can be made visible.

\section{Elsa's question matures (Act II, Scene 5; Act III, Scene 2)}

The light and joy at the end of Act I is soon contrasted with the perfidious nighttime conversation between Ortrud and Telramund that opens Act II. Now the dominant mood is one of darkness, vengeance, and evil. As we enter into the world of Ortrud, we see that she is the dark force of the internal story. While Elsa's temptation does not originate with Ortrud, the latter makes every effort to incite Elsa. In Act II, Elsa makes preparations for her wedding as Ortrud keeps interrupting her. Telramund, disguised as a monk, also appears and insists that the people must know the knight's name, at which point Lohengrin defends himself:

\begin{tabular}{|l|l|}
\hline Lohengrin: & Lohengrin: \\
Ja, selbst dem König darf ich & Yes, I can resist even \\
wehren & the King, \\
und aller Fürsten höchsten Rat! & and the highest counsel of \\
Nicht darf sie Zweifels Last & princes! \\
beschweren, & The burden of doubt will not \\
sie sahen meine gute Tat! & trouble them; \\
Nur eine ist's, der muss ich & they saw my good deed! \\
Antwort geben: & Only one person must I answer: \\
Elsa ... & Elsa..
\end{tabular}




\begin{tabular}{|l|l|} 
(Er hält betroffen an, als er, & (Lohengrin stops in consternation \\
sich zu Elsa wendend, diese & as he turns to Elsa and notices \\
mit heftig wogender Brust in & that, with a heaving breast, she is \\
wildem inneren Kampfe vor & staring in front of herself, torn by \\
sich hinstarren sieht.) & a violent inward struggle) \\
Elsa! Wie seh' ich sie erbeben! & Elsa! How she trembles! \\
In wildem Brüten muss ich sie & I must protect her from \\
gewahren! & brooding wildly! \\
Hat sie betört des Hasses & Has the lying tongue of hatred \\
Lügenmund? & beguiled her? \\
O Himmel, schirm ihr Herz vor & O Heaven, protect her heart \\
den Gefahren! & from danger! \\
Nie werde Zweifel dieser & May this innocent one never be \\
Reinen kund! $3 \circ$ & plagued with doubts!
\end{tabular}

In the finale of Act II, Lohengrin asks Elsa if she feels she must pose the forbidden question. "Elsa, arise! In your hand, in your devotion lies the pledge of all happiness! Does the force of doubt not leave you in peace? Do you wish to put the question to me?" ${ }_{31}$ Elsa replies:

\begin{tabular}{|l|l|}
\hline (in heftiger innerer Aufregung & (deeply agitated and in a state \\
und in schamvoller Verwirrung) & of confused embarrassment) \\
Mein Retter, der mir Heil & My deliverer, who brought me \\
gebracht! & salvation! \\
Mein Held, in dem ich muss & My knight, in whom I must \\
vergehn! & melt away! \\
(mit Bedeutung und Entschluss) & (with determination and clarity) \\
Hoch über alles Zweifels Macht & High above the force of all doubt \\
soll meine Liebe stehn! & may my love standI \\
(Sie sinkt an seine Brust.) & (She sinks upon his breast.) \\
\hline
\end{tabular}

Elsa and Lohengrin are married, but in Act II, Scene 2, the marriage is not consummated, for on the wedding night Elsa asks the forbidden question, and Lohengrin is ensnared in a political plot. The moment of the question is chosen with extreme care. Lohengrin looks at the nuptial bed and says that they are now 
alone for the first time. Elsa prepares the ground for her question by innocently asking whether Lohengrin's secret is truly such that he must continue to remain silent. Lohengrin, growing apprehensive, responds:

\begin{tabular}{|l|l|}
\hline Lohengrin: & Lohengrin: \\
An meine Brust, du Süsse, & Come to me, O sweet, \\
Reine! & pure one! \\
Sei meines Herzens Glühen nah, & Be near my ardent heart, \\
dass mich dein Auge sanft & that the eyes in which I saw all \\
bescheine, & my happiness \\
in dem ich all mein Glück ersah! & may shine upon me softly! \\
(feurig) & (passionately) \\
Gönne mir, dass mit Entzücken & O, grant me that in sweet raptures \\
ich deinen Atem sauge ein: & I may breathe in your breath: \\
lass fest, ach fest, an mich dich & O, let me clasp you to me so \\
drücken, & very firmly, \\
dass ich in dir mög' glücklich sein! & that I may be happy in you! \\
Dein Lieben muss mir hoch & Your love must be the highest \\
entgelten & recompense \\
für das, was ich um dich & for that which I left behind for \\
verliess; & your sake; \\
kein Los in Gottes weiten Welten & no destiny in all God's world \\
wohl edler als das meine hiess. & could have been nobler than mine. \\
Bot' mir der König seine Krone, & If the king offered me his crown, \\
ich dürfte sie mit Recht & I should rightfully \\
verschmähn. & reject it. \\
Das einz'ge, was mein Opfer & The only reward for my \\
lohne, & sacrifice \\
muss ich in deiner Lieb' ersehn! & is your steadfast love! \\
Drum wolle stets den Zweifel & Thus do I ask you to put doubt \\
meiden, & from your mind, \\
dein Lieben sei mein stolz & may your love be my proud \\
Gewähr! & guarantee! \\
Denn nicht komm' ich aus & For I come not from darkness \\
Nacht und Leiden, & and suffering, \\
aus Glanz und Wonne komm' & I come from splendour and \\
ich her! ${ }^{2}$ & delight! \\
\hline
\end{tabular}


Lohengrin imposes a great demand on Elsa: "Your love must be the highest recompense for that which I left behind for your sake." Just as in stating the injunction about his name, Lohengrin here speaks mostly about himself - and Elsa's debt of gratitude keeps growing. It is not enough that she was placed in a position of total submission in Act I. Lohengrin invokes the splendor and honor he has relinquished on her behalf so she must feel obliged to concede to his terms.

The emotional tragedy is constructed upon Elsa's uncertainty and desire for knowledge, which contrasts with the Wagnerian paradigm that the woman must love at any cost and redeem the man through her love. With the emotional dissonance of the question growing in Elsa's mind, the audience is riveted, secretly hoping that Elsa will refrain from asking the fateful question.

But in the end she does: "Nothing can bring me peace, nothing can tear me from my madness, save - even if it should cost me my life - knowing who you are!" Lohengrin cries in reply: "Elsa, what are you saying?" But she persists: "Ill-fatedly noble man! Hear the question I must ask you! Tell me your name!" 33 Posing the question makes inevitable the tragic parting - not only because Elsa has proven incapable of keeping her promise, but because, above all, the knight of the Holy Grail cannot satisfy the conditions of humanity. For Elsa's part, she is compelled to know the identity of her beloved in order for their love to become a shared project; she wants to be initiated into whatever it is that governs his life.

The forbidden question has grave consequences, not only for Elsa but for Lohengrin as well. Although he has told Elsa that he has come from a region of splendor and delight and abandoned all measure of wonderful things for her, Elsa's challenge to his identity causes him to abandon her and return to the realm of the Grail. Confronted by human demands, his divine power appears to fail him.

\section{The story of the Grail (Act III, Scene 3)}

With the troops summoned for an early morning assembly, and as trumpets sound and the woodwinds play a stirring march, a 
heartbroken Elsa and an anguished Lohengrin step before the king. The opera reaches its climax in Lohengrin's story of the Grail, beginning In fernem Land (In a far-off land). Lohengrin, who until this moment has only been addressed as a knight or protector, now discloses his true identity, marking the end of the internal action.

\begin{tabular}{|l|l|}
\hline $\begin{array}{l}\text { Lohengrin: } \\
\text { (in feierlicher Verklärung vor } \\
\text { sich hinblickend) }\end{array}$ & $\begin{array}{l}\text { Lohengrin: } \\
\text { (gazing forward, solemnly } \\
\text { transfigured) }\end{array}$ \\
In fernem Land, unnahbar & In a far-off land, inaccessible to \\
liegt eine Burg, die Montsalvat & your steps, \\
genannt; & there is a castle by the name of \\
ein lichter Tempel stehet dort & a light-filled temple stands \\
inmitten, & within it, \\
so kostbar als auf Erden nichts & more precious than anything on \\
bekannt; & earth; \\
drin ein Gefäss von & therein is a vessel of wonderous \\
wundertät'gem Segen & blessing \\
wird dort als höchstes & that is watched over as a sacred \\
Heiligtum bewacht: & relic: \\
es ward, dass sein der Menschen & that the purest of men might \\
reinste pflegen, & guard it, \\
herab von einer Engelschar & it was brought down by a host \\
gebracht; & of angels; \\
alljährlich naht vom Himmel & every year a dove descends \\
eine Taube, & from Heaven \\
um neu zu stärken seine & to fortify its wonderous \\
Wunderkraft: & power: \\
es heisst der Gral, und selig & it is called the Grail, and the \\
reinster Glaube & purest, most blessed faith \\
erteilt durch ihn sich seiner & is imparted through it to the \\
Ritterschaft. & Brotherhood of Knights. \\
Wer nun dem Gral zu dienen ist & Whosoever is chosen to serve \\
erkoren, & the Grail \\
den rüstet er mit überirdischer & is armed by it with heavenly \\
Macht; & power; \\
&
\end{tabular}




\begin{tabular}{|c|c|}
\hline $\begin{array}{l}\text { an dem ist jedes Bösen Trug } \\
\text { verloren, } \\
\text { wenn ihn er sieht, weicht dem } \\
\text { des Todes Nacht. } \\
\text { Selbst wer von ihm in ferne } \\
\text { Land' entsendet, } \\
\text { zum Streiter für der Tugend } \\
\text { Recht ernannt, } \\
\text { dem wird nicht seine heilige } \\
\text { Kraft entwendet, } \\
\text { bleibt als sein Ritter dort er } \\
\text { unerkannt; } \\
\text { so hehrer Art doch ist des } \\
\text { Grales Segen, } \\
\text { enthüllt muss er des Laien Auge } \\
\text { fliehn; } \\
\text { des Ritters drum sollt Zweifel } \\
\text { ihr nicht hegen, } \\
\text { erkennt ihr ihn - dann muss er } \\
\text { von euch ziehn. } \\
\text { Nun hört, wie ich verbot'ner } \\
\text { Frage lohne! } \\
\text { Vom Gral ward ich zu euch } \\
\text { daher gesandt: } \\
\text { mein Vater Parzival trägt seine } \\
\text { Krone, } \\
\text { sein Ritter ich - bin Lohengrin } \\
\text { genannt.34 }\end{array}$ & $\begin{array}{l}\text { every evil deceit is powerless } \\
\text { against him, } \\
\text { once he has seen it, the shadow } \\
\text { of death flees him. } \\
\text { Even he who is sent by it to a } \\
\text { distant land, } \\
\text { appointed as a champion of } \\
\text { virtue, } \\
\text { will not be robbed of its holy } \\
\text { power, } \\
\text { provided that he, as its knight, } \\
\text { remains } \\
\text { unrecognised there. } \\
\text { For so wondrous is the blessing } \\
\text { of the Grail } \\
\text { that when it is revealed it shuns } \\
\text { the eye of the uninitiated; } \\
\text { thus no man should doubt the } \\
\text { knight, } \\
\text { for if he is recognised, he must } \\
\text { leave you. } \\
\text { Hear how I reward the } \\
\text { forbidden question! } \\
\text { I was sent to you by the Grail: } \\
\text { my father Parzival wears its } \\
\text { crown, } \\
\text { I, its knight - am called } \\
\text { Lohengrin. }\end{array}$ \\
\hline
\end{tabular}

The final scene is heartrending. The knight of the Holy Grail, who laid down the conditions of his love with a stern divine injuction and then angrily accused Elsa of betrayal, is now shown to be a deeply suffering man, gathering the last of his strength to depart forever. Elsa had occasioned an opportunity for him to flee from the emotionally alienated, semi-divine life he led as a knight and enter the world of men. However, her posing the forbidden question has made all that impossible. The foundation of trust broken, Lohengrin must withdraw from the human sphere to resume his 
life in service of the Grail. In the final scene a forlorn Elsa looks on as her equally forlorn husband slowly recedes, never to return.

\section{Musical seduction: Spiritual missionary position}

Lohengrin is a cruel drama. How can it then seduce the spectator? In Angel's Cry: Beyond the Pleasure Principle in Opera, Michel Poizat uses Lacanian psychoanalysis to explore why opera arouses such powerful emotions in an audience. He concludes that operagoers are in search of jouissance - eroticized, orgasmic pleasure. A musical-dramatic trajectory from a seductive introduction to a wrenching climax seems to be fundamental to opera, but this may be said of other musical genres as well. From the organ fugues of J.S. Bach to the symphonies of Johannes Brahms, music can call forth enormous libidinal energy, which is then either allowed to well up or is controlled to some degree. This view is supported by Wayne Koestenbaum in The Queen's Throat: Opera, Homosexuality and the Mystery of Desire, and by Sam Abel in Opera in the Flesh: Sexuality in Operatic Performance. ${ }^{35}$

As stated in Chapter I, the term "body genre" used by Linda Williams to describe the type of film that elicits ecstatic feelings (from ex- "out of" and stasis "state of being") seems almost tailored for opera. ${ }^{36}$ The word melo(s) in melodrama refers to an excess of music, while drama stands for the action that is performed. Emotion - so powerful that ordinary speech is incapable of expressing it - bursts forth in opera in the form of song, modulated through the intermediary of trained voices. Williams describes the effects of body genre as follows:

A pertinent feature shared by these body genres is the focus on what could probably best be called a form of ecstasy. Contemporary meanings suggest components of direct or indirect sexual excitement and rapture, a rapture which informs even the pathos of melodrama.

Visually ecstatic excesses could be said to share a quality of uncontrollable convulsion or spasm - of the body "beside itself" with sexual pleasure. Aurally excess is marked by recourse not to the coded articulations of language but to inarticulate cries. ${ }^{37}$ 
Ecstasy in operatic art is often associated with the union of love, sexuality, and death. The ideal love scene for Wagner is Liebestod, a mystical union of two lovers in death. Tristan and Isolde sing as one: "Now banish dread, sweet death - yearned for, longed for death-in-love! In your arms, consecrated to you, sacred elemental quickening force, free from the peril of waking!" ${ }^{8}$ Isolde dies at the moment of her musical climax. The ecstatic nature of the death is underscored in both the music and the libretto, and the scene ends with the words höchste Lust (utmost rapture). The stage directions for the end of the same opera read: "Isolde sinks gently, as if transfigured, in Brangäne's arms, onto Tristan's body. Those looking on are awed and deeply moved. Mark blesses the bodies. The curtain falls slowly." 39 We are reminded of Hélène Cixous's funeral metaphor that links women, opera, sexuality, love, and death.

Many popular operas end with a dying tenor who embraces a lifeless, passive soprano or collapses onto her. Such a final gesture is emblematic of despair; it communicates to the audience a combined visual symbol of death/intercourse in a classic missionary position with the man on top and the passive, receiving woman under him. Examples include Tannhäuser, Luisa Miller, Rigoletto (with father and daughter), La Traviata, Aida, Otello, Romeo and Juliet, Carmen, Lakmé, La Gioconda, Pagliacci (two men, one alive, one dead, on top of a woman's body), Manon, Manon Lescaut, La Bohème, Madama Butterfly, and potentially all three acts of Les Contes d'Hoffmann. Abel wryly adds that Richard Strauss pours an entire regiment of soldiers on top of Salome for good measure. ${ }^{4 \circ}$

In some cases, the difference between this symbolic union in death and straightforward rape is very subtle. However, what is relevant about the final gesture is not sexuality, but its function as an expression of the woman's submissiveness. According to Susan McClary, the operatic orgasm makes the audience thirst for Carmen's death, to give just one example. The desire is not satisfied until Don José has stabbed Carmen, thereby symbolically raping and vanquishing the rebellious woman. ${ }^{4 \mathrm{I}}$

Wagner develops a very systematic emotional drama in Lohengrin, making it logical for Elsa to ask the forbidden question, which simultaneously is the worst possible form of betrayal. The dream lays bare the starting point of the love story; the taboo 
inquiry reveals the underlying conditions of the relationship; and the disaster triggered by Elsa in the wedding chamber culminates in the story of the Holy Grail. The audience breathes in time to the ineluctable question swelling in Elsa's mind. Although asking the question may be reasonable from a human standpoint, it clashes with the moral dramaturgy of the opera, which requires that at least one head must fall. We need a betrayal and someone who is both victim and scapegoat, or else the operatic orgasm will not be achieved.

Lohengrin links the issue of knowing to Elsa's position as an innocent victim who blames herself for asking the most natural of questions: who are you, my love? A moment before Elsa begins to tell us her dream, the leitmotif of the Grail resounds with a rising interval that in Wagner's music is termed the "defiant fourth." It represents pure faith in which "eyes are fixed on Heaven," whose blue and silver are the colors of the knights of the Holy Grail. ${ }^{2}$ The audience is reminded of the sublime goal of love: the highest good that admits no doubt.

Wagner even denies Elsa a Liebestod. Her humiliation is complete. The conclusion of Lohengrin marks Elsa's sole destruction, as Lohengrin frees the swan from Ortrud's spell, and Elsa's brother Gottfried is returned to the people. Although Lohengrin does not fall dead over Elsa, she swoons into the arms of her brother as Lohengrin slowly withdraws. Amid the grief over Lohengrin's farewell, the Grail leitmotif sounds a note of consolation and hope. Gottfried becomes the new ruler of Brabant and the triumph of masculine homosociality is complete.

While the opera is named after Lohengrin, its thematic heroine is Elsa. We follow her development and tragedy more closely than anyone else's. Yet all power remains concentrated in Lohengrin, confirming once more, as Teresa de Lauretis has written, “The hero, the mythical subject, is constructed as human being and as male; he is the active principle of culture." 43

From a feminist perspective, the emotional dramaturgy of Lohengrin promulgates a moral universe in which standards and values are patriarchally defined through the forbidden question and the story of the Grail. A woman's fidelity and loyalty are crucial for the consummation of the love project. However, in keeping with 
this ideology, the opera makes no mention of the gendered system upon which its characters are based. It is up to the feminist beholder to use counter-reading to make visible what the opera chooses to ignore.

\section{Notes}

I. Walsh, Keine Angst, I 57.

2. McClary Feminine Endings, 36.

3. Nieder, Von der Zauberflöte zum Lohengrin,” I 2. See also Honolka, Kulturgeschichte des Librettos; Scherle, Das deutsche Opernlibretto; Smith, The Tenth Muse.

4. Austin, Feminist, I-2.

5. Weigel, Der Schielende Blick.

6. Fetterley, The Resisting Reader.

7. Kaplan, "Is the Gaze Male?”, 23 I.

8. Melberg, Aristotle's Poetics.

9. Case, Feminism and Theatre, I I-I 2.

Io. Ibid., 5-27.

II. Cixous, "Aller à la mer,"I33-I36: "Comment, femme, peut-on aller au théâtre? Sauf à s'y trouver en complicité avec le sadisme dont les femmes y sont l'objet. A se voir invité à prendre, dans la structure familiale-patriarcale, que le théâtre reproduit à l'infini, la place de la victime. Qui est elle? Toujours la fille-du-père, son objet à sacrifier, gardienne du phallus et support du fantasme narcissique à l'aide duquel de père pare à la menace de castration."

I2. Clément's book, L'opéra ou la défaite des femmes (I979), did not attract attention until the publication of its English translation, Opera or the Undoing of Women, in 1988.

I 3. Abbate, “Opera” and “In search of Opera.” See also Koestenbaum, The Queen's Throat.

I4. Barthes, "Le grain de la voix.” For an introduction to Barthes's later writing, see Kolesch, Roland Barthes. 
I 5. This pair of semiotic concepts refers to two levels of the sign and can be also regarded as denoting expression/content.

I6. Wagner, Dichtungen und Schriften, 238.

I7. Ibid., I I 4-I I 5 .

I8. The categories are based on a lecture entitled The Woman of the Future: Women and Women's Voices in Wagner's Oeuvre given by German musicologist Susanne Vill at the University of Stockholm in November 1996. See Vill, "Das Weib der Zukunft"; Parly, Vocal Victories; Riegel, Richard Wagner's Women.

I9. Wagner, Dichtungen und Schriften, 238.

20. Ralf, Comments on Lohengrin, 35

2I. Palm, Wagners Lohengrin, 5 I.

22. Voss, Instrumentation Richard Wagners Lohengrin, I 27.

23. English translations of the librettos are taken from http://www. rwagner.net.

24. Wagner, Lohengrin, 3-4.

25. Wagner, Der fliegende Holländer, I4 (II 2-3).

26. Palm, Wagners Lohengrin, 26I.

27. Ibid.

28. Wagner, Lohengrin, 8.

29. Tchaikovsky, a great admirer of Lohengrin, based the main theme of Swan Lake on the Frageverbot.

30. Wagner, Lohengrin, p. 23

3 I. Ibid., 24.

32. Ibid., 28.

33. Ibid., 29.

34. Ibid., 29-30.

35. Poizat, Angel's Cry; Koestenbaum, The Queen's Throat; Abel, Opera in the Flesh.

36. Williams, "Film Bodies," 3. 
37. Ibid., 4 .

38. Wagner, Tristan und Isolde, 27.

39. Ibid., 42-43.

40. Abel, Opera in the Flesh, 94.

4I. McClary, Feminine Endings, 22.

42. Ralf, Comments on Lohengrin, 36.

43. de Lauretis, Alice Doesn't, I I8-I I9.

\section{Works Cited}

Abbate, Carolyn. "Opera; or, the Envoicing of Women.” In Musicology and Difference: Gender and Sexuality in Music Scholarship, edited by Ruth A. Solie, 225-258. Berkeley: University of California Press, I993.

$200 I$.

Abel, Sam. Opera in the Flesh: Sexuality in Operatic Performance. Boulder, CO: Westview Press, I996.

Austin, Gayle. Feminist Theories for Dramatic Criticism. Ann Arbor: University of Michigan Press, I990.

Barthes, Roland. "Le grain de la voix.” In L'oblivie et l'obtus. Essais critiques III, 236-245. Paris: Éditions de Seuil, I982.

Case, Sue-Ellen. Feminism and Theatre. New York: Routledge, I988.

Cixous, Hélène. “Aller à la mer." In Twentieth Century Theatre: A Sourcebook, edited by Richard Drain, I33-I 35 . London: Routledge, I995. Originally published in Le Monde, 28 April, I977. English translation in Modern Drama 27, no. 4 (I984): 546-548.

Clément, Catherine. Opera, or the Undoing of Women. London: Tauris, I997.

de Lauretis, Teresa. Alice Doesn't: Feminism, Semiotics, Cinema. Bloomington: Indiana University Press, I984.

Drain, Richard, ed. Twentieth Century Theatre: A Sourcebook. London: Routledge, I995. 
Fetterley, Judith. The Resisting Reader: A Feminist Approach to American Fiction. Bloomington: Indiana University Press, 1978.

Honolka, Kurt. Kulturgeschichte des Librettos: Opern, Dichter, Operndichter. Wilhelmshaven: Heinrichshofen, I979.

Kaplan, E. Ann. "Is the Gaze Male?" In Women and Values: Readings in Recent Feminist Philosophy, edited by Marilyn Pearsall, 289302. Belmont, CA: Wadsworth, 1986.

Koestenbaum, Wayne. The Queen's Throat: Opera, Homosexuality, and the Mystery of Desire. London: Penguin, I993.

Kolesch, Doris. Roland Barthes. Frankfurt: Campus Verlag, I997.

McClary, Susan. Feminine Endings: Music, Gender, and Sexuality. Minneapolis: University of Minnesota Press, I99I.

Melberg, Arne. "Introduktion.” In Om diktkonsten. Swedish translation of Aristotle's Poetics by Jan Stolpe. Göteborg: Anamma, I996.

Nieder, Christoph. Von der "Zauberflöte" zum "Lohengrin." Das deutsche Opernlibretto in der ersten Hälfte des I9. Jahrhunderts. Stuttgart: Metzler, I989.

Palm, Helga-Maria. Richard Wagners Lohengrin. Studien zur Sprachbehandlung. München: Wilhelm Fink Verlag, I987.

Parly, Nila. Vocal Victories. Wagner's Female Characters from Senta to Kundry. Chiccago: Chicago University Press, 201 I.

Poizat, Michel. Angel's Cry: Beyond the Pleasure Principle in Opera. Ithaca: Cornell University Press, I992.

Ralf, Klas. Comments on Lohengrin, A Romantic Opera in Three Acts. Stockholm: Royal Opera, I974.

Rieger, Eva. Richard Wagner's Women. New York: Boydell Press, 20 I I.

Scherle, Arthur. Das deutsche Opernlibretto von Opitz bis Hoffmansthal. Dissertation. München: Ludwig-MaximiliansUniversität München, I954.

Smith, Patrick J. The Tenth Muse: A Historical Study of the Opera Libretto. London: Gollantz, I97I.

Vill, Susanne, ed. Das Weib der Zukunft. Frauengestalten und Frauenstimmen bei Richard Wagner. Stuttgart: Metzler, 2000. 
Voss, Egon. Studien zur Instrumentation Richard Wagners. Regensburg: Bosse Verlag, I970.

Wagner, Richard. Lohengrin, A Romantic Opera in Three Acts. Libretto in German and Swedish, sheet music excerpts, and annotations. Stockholm: Royal Opera, I974.

Tristan und Isolde. Libretto in German and Swedish, presentation of leitmotifs with sheet attachment. Stockholm: Royal Opera, I974.

- Der fliegende Holländer, A Romantic Opera in Three Acts. Libretto in German and Swedish, sheet music excerpts, and annotations. Stockholm: Royal Opera, I977.

Bänden. Vol. VI. Frankfurt: Insel Verlag, I983.

Walsh, Michael. Keine Angst vor der Oper. München: Piper Verlag, I 997.

Weigel, Sigrid. Der Schielende Blick: Thesen zur Geschichte weiblicher Schreibpraxis. Die verborgene Frau. Berlin: Argument Verlag, I983.

Williams, Linda. "Film Bodies: Gender, Genre, and Excess." Film Quarterly 44 (I99I): 2-I3. 